\title{
Ru complexes of Hoveyda-Grubbs type immobilized on lamellar zeolites: activity in olefin metathesis reactions
}

\author{
Hynek Balcar, Naděžda Žilková, Martin Kubů, Michal Mazur, Zdeněk Bastl and Jiří Čejka
}

\author{
Full Research Paper \\ Address: \\ J. Heyrovský Institute of Physical Chemistry, Academy of Sciences of \\ the Czech Republic, v.v. i. Dolejškova 2155/3, 18223 Prague 8, \\ Czech Republic \\ Email: \\ Hynek Balcar - hynek.balcar@jh-inst.cas.cz \\ * Corresponding author \\ Keywords: \\ Hoveyda-Grubbs type catalyst; hybrid catalysts; lamellar zeolites; \\ non-covalent immobilization; olefin metathesis
}

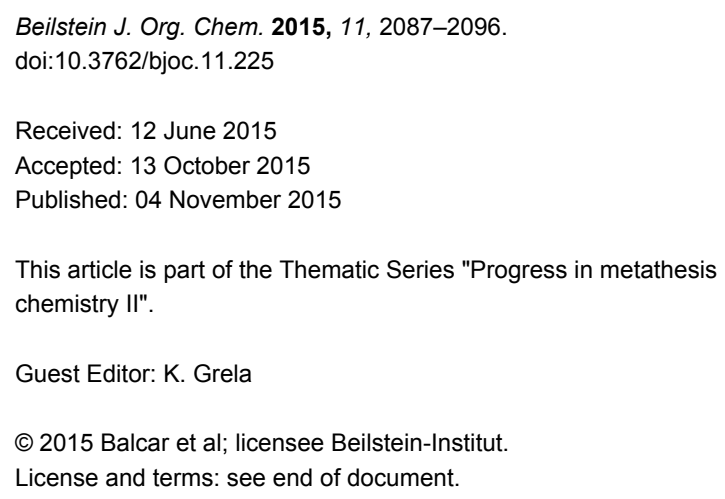

\begin{abstract}
Hoveyda-Grubbs type catalysts with cationic tags on NHC ligands were linker-free immobilized on the surface of lamellar zeolitic supports (MCM-22, MCM-56, MCM-36) and on mesoporous molecular sieves SBA-15. The activity of prepared hybrid catalysts was tested in olefin metathesis reactions: the activity in ring-closing metathesis of citronellene and $N, N$-diallyltrifluoroacetamide decreased in the order of support MCM-22 $\approx$ MCM-56 > SBA-15 > MCM-36; the hybrid catalyst based on SBA-15 was found the most active in self-metathesis of methyl oleate. All catalysts were reusable and exhibited low Ru leaching ( $<1 \%$ of Ru content). XPS analysis revealed that during immobilization ion exchange between Hoveyda-Grubbs type catalyst and zeolitic support occurred in the case of $\mathrm{Cl}^{-}$counter anion; in contrast, $\mathrm{PF}_{6}{ }^{-}$counter anion underwent partial decomposition.
\end{abstract}

\section{Introduction}

Immobilization of Ru alkylidene complexes (Grubbs and Hoveyda-Grubbs type catalysts) on siliceous supports represents a successful way to highly active, selective, and reusable metathesis catalysts [1-4]. Mesoporous molecular sieves (MCM-41, MCM-48, SBA-15), with large BET areas and pore volumes, proved to be very suitable supports, due to easy attachment of bulky organometallic complexes onto silica surface ensuring rapid diffusion of reactants to the active catalytic sites [5-12]. Several strategies of immobilization have been developed $[1,5,13]$; most of them are based on surface modification by specially designed linkers providing covalent bond linkage between the support and Ru complex. Hoveyda-Grubbs type catalysts are also capable of direct (linker-free) immobilization by means of non-covalent interac- 
tions [8,14-20]. Although the character of this interaction is not completely clear, they are firm enough to ensure low $\mathrm{Ru}$ leaching and catalyst reusability.

Recently, we reported Hoveyda-Grubbs type catalysts bearing quaternary ammonium tag on $\mathrm{NHC}$ ligand $\left(\mathrm{HGIIN}^{+} \mathrm{X}\right.$, where $\mathrm{X}=\mathrm{Cl}^{-}, \mathrm{I}^{-}, \mathrm{PF}_{6}{ }^{-}$, or $\mathrm{BF}_{4}{ }^{-}$) and their immobilization on silica, and mesoporous molecular sieves MCM-41 and SBA-15 [21]. XPS analysis revealed that complexes were attached to the surface by non-covalent interactions and both cationic and anionic parts were present on the surface. The hybrid catalysts prepared were active in $\mathrm{RCM}$ of 1,7-octadiene and (-)- $\beta$-citronellene; $\mathrm{HGIIN}^{+} \mathrm{Cl}^{-}$on $\mathrm{SBA}-15\left(\mathrm{HGIIN}^{+} \mathrm{Cl}^{-}\right.$/ SBA-15) was the most active (TON up to 16000 in RCM of citronellene). $\mathrm{HGIIN}^{+} \mathrm{Cl}^{-} / \mathrm{SBA}-15$ proved its versatility in RCM, enyne metathesis, metathesis of methyl oleate, and crossmetathesis of electron deficient methyl acrylate with various co-substrates. The catalyst was reusable and $\mathrm{Ru}$ leaching was very low, not only in toluene ( $\mathrm{Ru}$ content in product $<10 \mathrm{ppm}$ in most cases) but also in polar solvents (ethyl acetate, dichloromethane, leaching about $1 \%$ of Ru content in catalyst). A similar ammonium-tagged Hoveyda-Grubbs type catalyst with sterically enlarged NHC ligand supported on SBA-15 exhibited high stability and was effective in flow reactions [22].

According to our knowledge, zeolites have not been considered as perspective supports for the immobilization of Ru metathesis catalysts due to small diameters of their pores $(<1 \mathrm{~nm})$ not allowing to anchor appropriate alkylidene complexes in the channel system and to ensure accessibility of catalytic centers by reactants. However, new methods for the preparation of lamellar (also called two-dimensional) zeolite with high surface area and layered structure have been developed [23] and such zeolites offer the possibility of their modifications with organometallic moieties in a similar way as mesoporous molecular sieves. Limbach et al. [20] used MWW material as a support for $\mathrm{Ru}$ heterogeneous catalyst for cyclooctene oligomerization, however, its activity was rather low. In this article we discuss the immobilization of $\mathrm{HGIIN}^{+} \mathrm{Cl}^{-}$and $\mathrm{HGIIN}^{+} \mathrm{PF}_{6}{ }^{-}$(Figure 1) on zeolitic supports having MWW structure: MCM-22 (three-dimensional), MCM-56 (unilamellar), and MCM-36 (pillared) and the activity of corresponding catalysts (i) in RCM of (-)- $\beta$-citronellene and $N, N$-diallyl-2,2,2-trifluoroacetamide (DAF), and (ii) in selfmetathesis and cross-metathesis of methyl oleate.

Lamellar (two dimensional) zeolites represent a subgroup of zeolitic materials, in which one of the dimension of the crystals is usually limited to $2-3 \mathrm{~nm}$ and is around one unit cell [24,25]. Depending on the structure of the prepared zeolite, the individual zeolitic layers exhibit or do not exhibit micropore char-

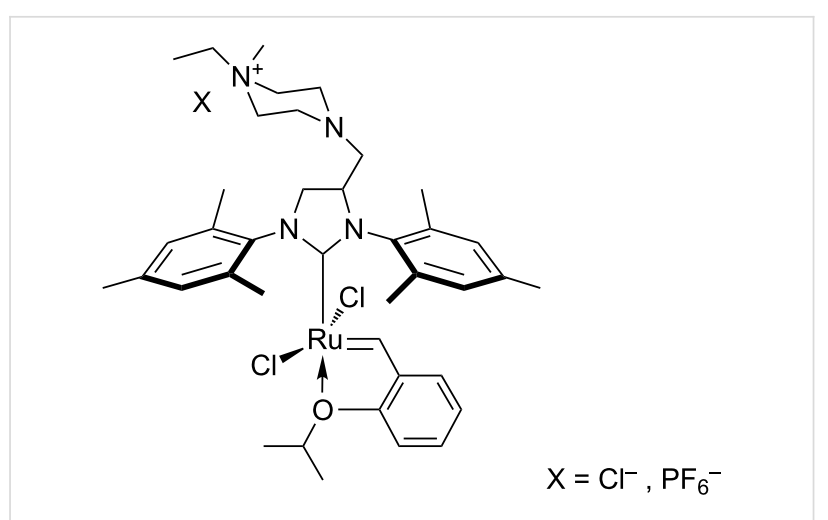

Figure 1: Hoveyda-Grubbs type catalysts used for immobilization.

acter. Two dimensional zeolites are usually prepared by a bottom-up hydrothermal synthesis [26]; recently also a topdown approach from germanosilicate zeolite UTL was reported [27]. The latter approach utilizes chemically selective hydrolysis of $\mathrm{Ge}-\mathrm{O}$ bonds to form layers from three-dimensional zeolites [28]. Generally, two-dimensional zeolites possess BET areas above $500-600 \mathrm{~m}^{2} / \mathrm{g}$, which is comparable with mesoporous molecular sieves. The surface of two-dimensional zeolites can be modified with various organic ligands to induce adsorption or catalytic functionalities [29,30]. The detailed structures of zeolites MCM-22, MCM-36 and MCM-56 used as supports in this work are depicted in $[31,32]$.

\section{Results and Discussion Hybrid catalyst preparation and characterization}

Immobilization of $\mathrm{HGIIN}^{+} \mathrm{X}$ complexes proceeded smoothly by mixing their solutions with dry supports at room temperature. In the case of $\mathrm{HGIIN}^{+} \mathrm{Cl}^{-}$and MCM-22, MCM-56, and SBA-15, the immobilization was nearly quantitative (97-99\% of Ru was attached to the support, see Experimental). However, in other cases $\left(\mathrm{HGIIN}^{+} \mathrm{Cl}^{-}+\mathrm{MCM}-36\right.$ and $\left.\mathrm{HGIIN}^{+} \mathrm{PF}_{6}{ }^{-}+\mathrm{MCM}-22\right)$ only part of $\mathrm{Ru}$ submitted for immobilization was captured on the support under condition applied. In this way, hybrid catalysts $\mathrm{HGIIN}^{+} \mathrm{Cl}^{-} / \mathrm{MCM}-22$ (1.1 wt \% Ru), $\mathrm{HGIIN}^{+} \mathrm{Cl}^{-}$/ MCM-56 (1.1 wt \% Ru), $\mathrm{HGIIN}^{+} \mathrm{Cl}^{-} / \mathrm{MCM}-36$ (0.7 wt \% Ru), $\mathrm{HGIIN}^{+} \mathrm{PF}_{6}{ }^{-} / \mathrm{MCM}-22$ (0.9 wt \% Ru), and $\mathrm{HGIIN}^{+} \mathrm{Cl}^{-} / \mathrm{SBA}-15$ $(1.2 \mathrm{wt} \% \mathrm{Ru})$ were prepared.

Table 1 shows textural parameters of zeolitic supports and corresponding hybrid catalysts. The attachment of Ru complex brought about a significant decrease in $S_{\mathrm{BET}}$ and pore volume. Especially, the micropore volume strongly decreased. Due to the molecular size of Hoveyda-Grubbs $2^{\text {nd }}$ generation catalyst $(1.76 \times 1.35 \times 1.05 \mathrm{~nm}[15])$ the molecules of $\mathrm{HGIIN}^{+} \mathrm{Cl}^{-}$ cannot penetrate into micropores of MCM-22 or MCM-56 zeolites. The decrease in the micropore volume may suggest 
that molecules of catalyst are located in the mouths of pores and block the access to the micropore system. X-ray diffraction patterns showed (Supporting Information File 1, Figures S1, S2, and S3) that original structure of the parent supports was preserved. As concerns $\mathrm{HGIIN}^{+} \mathrm{Cl}^{-} / \mathrm{SBA}-15$, it was shown earlier [21] that the SBA-15 architecture was preserved; both $S_{\mathrm{BET}}$ and $V$ values were reduced in comparison with the parent SBA-15 (from $739 \mathrm{~m}^{2} / \mathrm{g}$ and $1.15 \mathrm{~cm}^{3} / \mathrm{g}$ to $492 \mathrm{~m}^{2} / \mathrm{g}$ and $0.92 \mathrm{~cm}^{3} / \mathrm{g}$, respectively) but the change in pore diameter was negligible (from 6.7 to $6.6 \mathrm{~nm}$ ).

Table 1: Textural parameters of MCM-22, MCM-56, MCM-36, and corresponding hybrid catalysts.

\begin{tabular}{lllll} 
Sample & $\begin{array}{l}S_{\mathrm{BET}} \\
\left(\mathrm{m}^{2} / \mathrm{g}\right)\end{array}$ & $\begin{array}{l}S_{\text {ext }^{\mathrm{a}}} \\
\left(\mathrm{m}^{2} / \mathrm{g}\right)\end{array}$ & $\begin{array}{l}V_{\text {mic }}{ }^{\mathrm{b}} \\
\left(\mathrm{cm}^{3} / \mathrm{g}\right)\end{array}$ & $\begin{array}{l}V_{\text {total }}{ }^{\mathrm{c}} \\
\left(\mathrm{cm}^{3} / \mathrm{g}\right)\end{array}$ \\
\hline $\mathrm{MCM}-22$ & 504 & 121 & 0.174 & 0.429 \\
$\mathrm{HGIN}^{+} \mathrm{Cl}^{-} / \mathrm{MCM}-22$ & 379 & 121 & 0.117 & 0.355 \\
$\mathrm{MCM}^{-56}$ & 446 & 171 & 0.124 & 0.555 \\
$\mathrm{HGIN}^{+} \mathrm{Cl}^{-} / \mathrm{MCM}-56$ & 157 & 119 & 0.015 & 0.324 \\
$\mathrm{MCM}^{36}$ & 658 & 564 & 0.041 & 0.364 \\
$\mathrm{HGIN}^{+} \mathrm{Cl}^{-} / \mathrm{MCM}-36$ & 488 & 426 & 0.027 & 0.268 \\
\hline
\end{tabular}

aExternal surface area, ${ }^{b}$ micropore volume ( $t$-plot method), ctotal pore volume at $p / p_{0}=0.95$, for evaluation of $S_{\mathrm{BET}}$, the interval of $p / p_{0}=$ $0.05-0.20$ was used.

The stoichiometry of the studied catalyst samples resulting from the XPS analysis is summarized in Table 2. A good agreement between the chemical composition of the neat compounds calculated from the integrated intensities of photoelectron spectra and their nominal stoichiometry was observed. For $\mathrm{HGIIN}^{+} \mathrm{Cl}^{-} / \mathrm{SBA}-15$ the atomic ratio $\mathrm{Cl} / \mathrm{Ru}=3$ indicates both cationic and anionic parts of the parent complex were present in the hybrid catalysts, as shown earlier [21]. In contrast to that, the atomic ratio $\mathrm{Cl} / \mathrm{Ru}=1.9$ for $\mathrm{HGIIN}^{+} \mathrm{Cl}^{-} / \mathrm{MCM}-22$ may indicate that $\mathrm{Cl}^{-}$remained in a liquid phase as $\mathrm{NaCl}$. For $\mathrm{HGIIN}^{+} \mathrm{PF}_{6}{ }^{-} / \mathrm{MCM}-22$ catalyst, the results suggest that reduction of the $\mathrm{PF}_{6}$ anion to the $\mathrm{PF}_{3}$ species took place in immobilized compound. In addition to it, the decrease in $\mathrm{Cl} / \mathrm{Ru}$ atomic ratio to 1.3 (1.4) may indicate change in the number of $\mathrm{Cl}$ ligands in the coordination sphere of $\mathrm{Ru}$ (at least a part of catalyst molecules was affected). The low concentration of the $\mathrm{Ru}$ complex in $\mathrm{HGIIN}^{+} \mathrm{PF}_{6}{ }^{-} / \mathrm{MCM}-22$ did not allow obtaining any detailed information.

\section{Catalyst activity in ring-closing metathesis}

Hybrid catalysts were tested in ring-closing metathesis (RCM) of (-)- $\beta$-citronellene and $N, N$-diallyl-2,2,2-trifluoroacetamide (DAF) (Scheme 1). Figure 2 shows conversion curves of RCM of (-)- $\beta$-citronellene over $\mathrm{HGIIN}^{+} \mathrm{Cl}^{-} / \mathrm{MCM}-22, \mathrm{HGIIN}^{+} \mathrm{Cl}^{-} /$ MCM-56, $\mathrm{HGIIN}^{+} \mathrm{Cl}^{-} / \mathrm{MCM}-36, \mathrm{HGIIN}^{+} \mathrm{PF}_{6}^{-} / \mathrm{MCM}-22$, and
Table 2: Atomic concentration ratios of $\mathrm{N}, \mathrm{F}, \mathrm{Cl}$, and $\mathrm{P}$ to $\mathrm{Ru}$ determined from $X P$ spectra for neat $\mathrm{HGIIN}^{+} X\left(X=\mathrm{Cl}^{-}, \mathrm{PF}_{6}{ }^{-}\right)$and hybrid catalysts $\mathrm{HGIIN}^{+} \mathrm{Cl}^{-} / \mathrm{MCM}^{-22}, \mathrm{HGIIN}^{+} \mathrm{Cl}^{-} / \mathrm{SBA}-15$, and $\mathrm{HGINN}^{+} \mathrm{PF}_{6}{ }^{-} /$ MCM-22. (For $\mathrm{HGIIN}^{+} \mathrm{PF}_{6}-\mathrm{MCM}^{-22}$ catalyst the results obtained on two independent sample preparations are displayed demonstrating the reproducibility.)

\begin{tabular}{lllll} 
Sample & $\mathrm{N}$ & $\mathrm{Cl}$ & $\mathrm{F}$ & $\mathrm{P}$ \\
\hline $\mathrm{HGIIN}^{+} \mathrm{Cl}^{-}$ & 4.2 & 3.0 & 0 & 0 \\
$\mathrm{HGIIN}^{+} \mathrm{Cl}^{-} / \mathrm{MCM}-22$ & 4.1 & 1.9 & 0 & 0 \\
$\mathrm{HGIN}^{+} \mathrm{Cl}^{-} / \mathrm{SBA}-15$ & 4.0 & 3.0 & 0 & 0 \\
$\mathrm{HGIIN}^{+} \mathrm{PF}_{6}{ }^{-}$ & 3.8 & 1.8 & 6.2 & 1.0 \\
$\mathrm{HGIN}^{+} \mathrm{PF}_{6}{ }^{-} / \mathrm{MCM}-22$ & 4.2 & 1.3 & 2.9 & 1.2 \\
& 4.0 & 1.4 & 3.2 & 0.85
\end{tabular}

$\mathrm{HGIIN}^{+} \mathrm{Cl}^{-} / \mathrm{SBA}-15$ for comparison (data taken from ref [21] for the last catalyst). It is seen that the activities of $\mathrm{HGIIN}^{+} \mathrm{Cl}^{-} /$ MCM-22, $\mathrm{HGIIN}^{+} \mathrm{Cl}^{-} / \mathrm{MCM}-56$, and $\mathrm{HGIIN}^{+} \mathrm{PF}_{6}{ }^{-} / \mathrm{MCM}-22$ were rather similar but significantly higher than that of $\mathrm{HGIIN}^{+} \mathrm{Cl}^{-} / \mathrm{SBA}-15$. The initial TOFs (calculated from conversion at $5 \mathrm{~min}$ ) were $4800 \mathrm{~h}^{-1}, 5500 \mathrm{~h}^{-1}$, and $2800 \mathrm{~h}^{-1}$ for $\mathrm{HGIIN}^{+} \mathrm{Cl}^{-} / \mathrm{MCM}-22, \mathrm{HGIIN}^{+} \mathrm{Cl}^{-} / \mathrm{MCM}^{-56}$, and $\mathrm{HGIIN}^{+} \mathrm{Cl}^{-} /$ SBA-15, respectively, and also the conversion after $300 \mathrm{~min}$ was higher for $\mathrm{HGIIN}^{+} \mathrm{Cl}^{-} / \mathrm{MCM}-22$ and $\mathrm{HGIIN}^{+} \mathrm{Cl}^{-} / \mathrm{MCM}-56$ (98\% and $97 \%$, respectively) than for $\mathrm{HGIIN}^{+} \mathrm{Cl}^{-} / \mathrm{SBA}-15$ $(81 \%)$. It demonstrates the superiority of both $\mathrm{HGIIN}^{+} \mathrm{Cl}^{-}$/ MCM-22 and $\mathrm{HGIIN}^{+} \mathrm{Cl}^{-} / \mathrm{MCM}-56$ catalysts in this reaction, originating probably from a better accessibility of catalytic centers. The conversion curve for $\mathrm{HGIIN}^{+} \mathrm{PF}_{6}{ }^{-} / \mathrm{MCM}-22$ was close to that for $\mathrm{HGIIN}^{+} \mathrm{Cl}^{-} / \mathrm{MCM}-22$, in spite of changes of $\mathrm{HGIIN}^{+} \mathrm{PF}_{6}{ }^{-}$structure in the course of immobilization as indicated by XPS. Surprisingly, conversions achieved with $\mathrm{HGIIN}^{+} \mathrm{Cl}^{-} / \mathrm{MCM}-36$ were lower than those achieved with $\mathrm{HGIIN}^{+} \mathrm{Cl}^{-} / \mathrm{MCM}-22$ and even with $\mathrm{HGIIN}^{+} \mathrm{Cl}^{-} / \mathrm{SBA}-15$, despite the pillared character of the MCM-36 support. Selectivity was $100 \%$ in all cases: only methylcyclopentene and isobutene were found as reaction products by GC-MS. Enantioselectivity was not established.

Similar dependence of catalytic activity on the type of support was found for RCM of DAF (Figure 3). The initial TOFs (calculated from conversion at $5 \mathrm{~min}$ ) decreased in the order: $\mathrm{HGIIN}^{+} \mathrm{Cl}^{-} / \mathrm{MCM}-22\left(1770 \mathrm{~h}^{-1}\right)>\mathrm{HGIIN}^{+} \mathrm{Cl}^{-} / \mathrm{MCM}-56$ $\left(1440 \mathrm{~h}^{-1}\right)>\mathrm{HGIIN}^{+} \mathrm{Cl}^{-} / \mathrm{SBA}-15\left(990 \mathrm{~h}^{-1}\right) \geq \mathrm{HGIIN}^{+} \mathrm{Cl}^{-} /$ MCM-36 $\left(900 \mathrm{~h}^{-1}\right)$. Final conversions (at $180 \mathrm{~min}$ ) were in the interval from $96 \%$ to $99 \%$. Similarly as for RCM of (-)- $\beta$-citronellene, hybrid catalysts $\mathrm{HGIIN}^{+} \mathrm{Cl}^{-} / \mathrm{MCM}-22$ and $\mathrm{HGIIN}^{+} \mathrm{Cl}^{-} / \mathrm{MCM}-56$ exhibited a higher activity than $\mathrm{HGIIN}^{+} \mathrm{Cl}^{-} / \mathrm{SBA}-15$. Although initial TOF for $\mathrm{HGIIN}^{+} \mathrm{Cl}^{-} /$ SBA-15 and for $\mathrm{HGIIN}^{+} \mathrm{Cl}^{-} / \mathrm{MCM}-36$ were close to each other; further progress of conversion curves indicated lower activity of $\mathrm{HGIIN}^{+} \mathrm{Cl}^{-} / \mathrm{MCM}-36$ in comparison with $\mathrm{HGIIN}^{+} \mathrm{Cl}^{-} / \mathrm{SBA}-15$. 

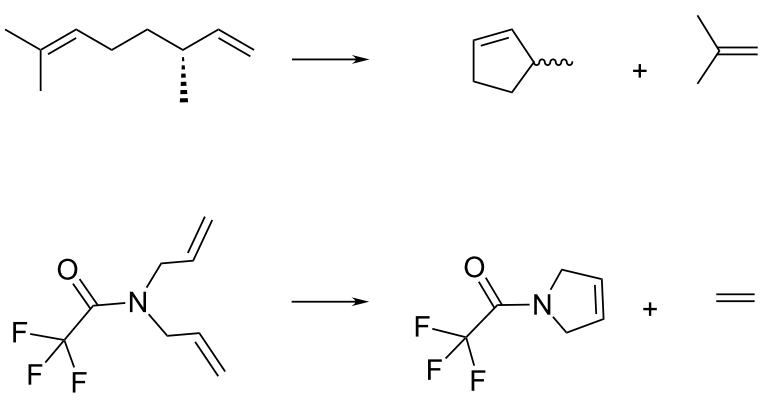

Scheme 1: RCM of (-)- $\beta$-citronellene (1) and $N, N$-diallyl-2,2,2-trifluoroacetamide (2).

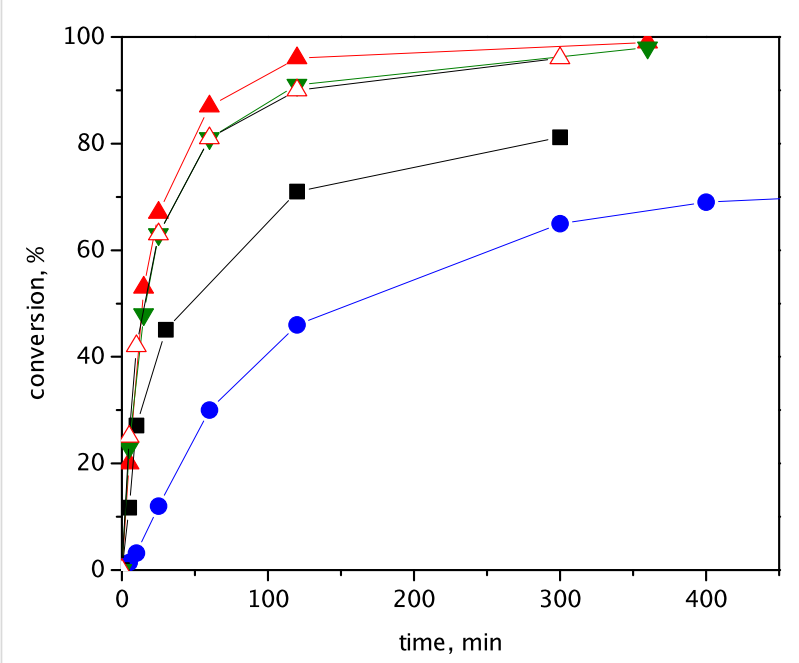

Figure 2: Conversion vs time dependence for RCM of $(-)-\beta$-citronellene over $\mathrm{HGIN}^{+} \mathrm{Cl}^{-} / \mathrm{MCM}-36(\bullet), \mathrm{HGIN}^{+} \mathrm{Cl}^{-} / \mathrm{SBA}-15(\bullet)$, $\mathrm{HGIN}^{+} \mathrm{Cl}^{-} / \mathrm{MCM}^{-22}(\boldsymbol{\Delta}), \mathrm{HGINN}^{+} \mathrm{PF}_{6}^{-} / \mathrm{MCM}^{-22}(\Delta)$, and $\mathrm{HGIN}^{+} \mathrm{Cl}^{-} /$ MCM-56 ( $\boldsymbol{\nabla})$. Toluene, $60{ }^{\circ} \mathrm{C}$, molar ratio $(-)-\beta$-citronellene $/ \mathrm{Ru}=2000$, $c_{\text {citr }}=0.15 \mathrm{~mol} / \mathrm{L}$.

The selectivity to $N$-(2-trifluoroacetyl)-2,5-dihydropyrrole was $100 \%$.

Catalyst leaching and reusing were studied in RCM of $(-)$ - $\beta$-citronellene. Figure 4 shows a splitting test [33] for $\mathrm{HGIIN}^{+} \mathrm{Cl}^{-} / \mathrm{MCM}-56.10$ min after the beginning of the reaction, a half of the liquid phase was filtered off into a parallel reactor further kept under the same reaction temperature. Metathesis reaction continued in the heterogeneous system only, which evidences no leaching of catalytically active species into the liquid phase. Ru leaching determined by elemental analysis in the reaction mixture after finishing the reaction was $0.3 \%, 0.1 \%$, and $0.6 \%$ of starting amount of $\mathrm{Ru}$ in catalyst for $\mathrm{HGIIN}^{+} \mathrm{Cl}^{-} / \mathrm{MCM}-22, \mathrm{HGIIN}^{+} \mathrm{Cl}^{-} / \mathrm{MCM}-56$, and $\mathrm{HGIIN}^{+} \mathrm{Cl}^{-} /$ $\mathrm{MCM}-36$, respectively. These values correspond to $1.2,0.4$, and $2.2 \mathrm{ppm}$ of $\mathrm{Ru}$ in the products, which is considerably lower than

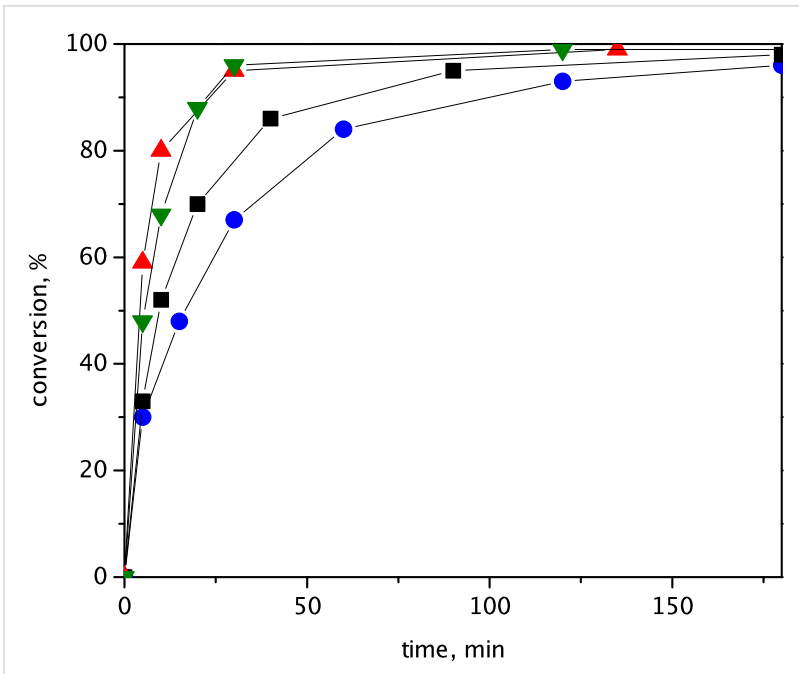

Figure 3: Conversion vs. time dependences for RCM of DAF over catalysts $\mathrm{HGIIN}^{+} \mathrm{Cl}^{-} / \mathrm{MCM}-22(\boldsymbol{\Delta}), \mathrm{HGIIN}^{+} \mathrm{Cl}^{-} / \mathrm{MCM}-56(\boldsymbol{\nabla})$, $\mathrm{HGIIN}^{+} \mathrm{Cl}^{-} / \mathrm{SBA}-15(\bullet)$, and $\mathrm{HGIIN}{ }^{+} \mathrm{Cl}^{-} / \mathrm{MCM}^{-36}(\bullet)$. Toluene, $30{ }^{\circ} \mathrm{C}$, molar ratio $\mathrm{DAF} / \mathrm{Ru}=250, c_{\mathrm{DAF}}=0.15 \mathrm{~mol} / \mathrm{L}$.

the $\mathrm{Ru}$ content in drugs recommended by the European Medicines Agency in 2007 (10 ppm for oral exposure) [34].

Results of $\mathrm{HGIIN}^{+} \mathrm{Cl}^{-} / \mathrm{MCM}-22$ reusing are displayed in Table 3. The catalyst was used 5 times without any decrease in the conversion. Due to the very low Ru leaching level (only $0.3 \%$ of the original amount of $\mathrm{Ru}$ was found in the combined samples from runs 1 to 5), the conversion drop after the fifth run must be ascribed to the catalyst deactivation. The cumulative TON achieved in 7 runs was 1491. The results evidence very firm attachment of catalytically active species to the surface of zeolites and their good stability.

\section{Catalyst activity in self-metathesis and cross-metathesis of methyl oleate}

Conversion curves for self-metathesis of methyl oleate over hybrid catalysts $\mathrm{HGIIN}^{+} \mathrm{Cl}^{-} / \mathrm{MCM}-22, \mathrm{HGIIN}^{+} \mathrm{Cl}^{-} / \mathrm{MCM}-56$, 
Table 3: $\mathrm{HGIIN}^{+} \mathrm{Cl}^{-} / \mathrm{MCM}-22$ reusing in $\mathrm{RCM}$ of (-)- $\beta$-citronellene. Toluene, $60{ }^{\circ} \mathrm{C}$, molar ratio $(-)-\beta$-citronellene/Ru $=1: 250, c_{\text {citr }}=0.15 \mathrm{~mol} / \mathrm{L}$, reaction time $2.5 \mathrm{~h}$.

$\begin{array}{llllllll}\text { Run } & 1 & 2 & 3 & 4 & 5 & 6 & 7 \\ \text { Conversion } & 99.5 \% & 99.5 \% & 99.5 \% & 99.5 \% & 99.5 \% & 72.5 \% & 26.5 \% \\ \text { Cumulative TON } & 249 & 498 & 746 & 995 & 1244 & 1425\end{array}$

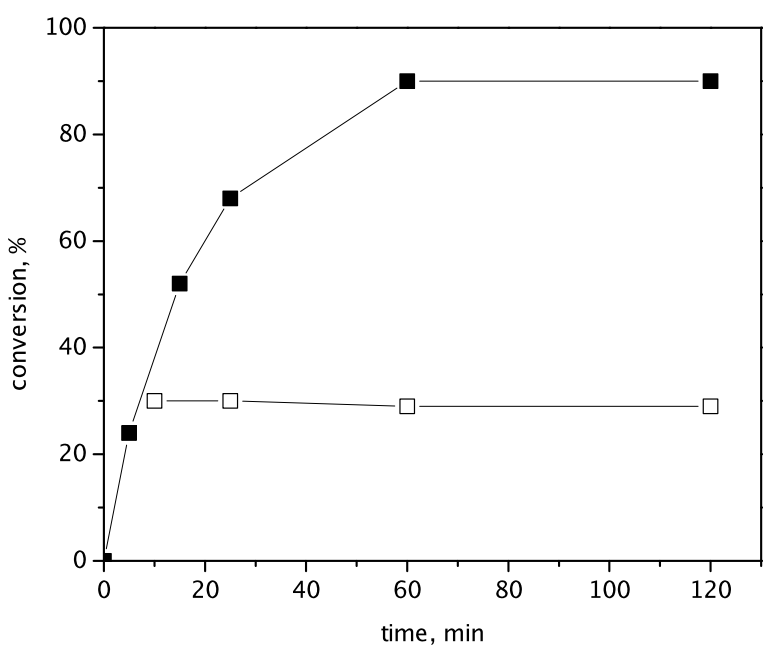

Figure 4: Splitting test for $\mathrm{HGIN}^{+} \mathrm{Cl}^{-} / \mathrm{MCM}-56$ in $\mathrm{RCM}$ of $(-)-\beta$-citronellene. Toluene, $60^{\circ} \mathrm{C}$, molar ratio (-)- $\beta$-citronellene/Ru $=$ $2000, c_{\text {citr }}=0.15 \mathrm{~mol} / \mathrm{L}$. Heterogeneous system $(\mathbf{\square})$, filtrate $(\square)$.

$\mathrm{HGIIN}^{+} \mathrm{Cl}^{-} / \mathrm{MCM}-36$, and $\mathrm{HGIIN}^{+} \mathrm{Cl}^{-} / \mathrm{SBA}-15$ in toluene at $60{ }^{\circ} \mathrm{C}$ are depicted in Figure 5. In contrast to $\mathrm{RCM}$ of $(-)-\beta$-citronellene and $\mathrm{RCM}$ of DAF, $\mathrm{HGIIN}^{+} \mathrm{Cl}^{-} / \mathrm{SBA}-15$ turned out to be the most active catalyst. The catalytic activity decreased in the order $\mathrm{HGIIN}^{+} \mathrm{Cl}^{-} / \mathrm{SBA}-15>\mathrm{HGIIN}^{+} \mathrm{Cl}^{-} /$ MCM-56 $\approx \mathrm{HGIIN}^{+} \mathrm{Cl}^{-} / \mathrm{MCM}-22>\mathrm{HGIIN}^{+} \mathrm{Cl}^{-} / \mathrm{MCM}-36$. Moreover, conversion curves for catalysts supported on zeolites exhibited an induction period repeatedly (very distinct for $\mathrm{HGIIN}^{+} \mathrm{Cl}^{-} / \mathrm{MCM}-22$ and $\left.\mathrm{HGIIN}^{+} \mathrm{Cl}^{-} / \mathrm{MCM}-36\right)$. This induction period became even more pronounced when the reaction temperature decreased to $30{ }^{\circ} \mathrm{C}$ and the activity gap between $\mathrm{HGIIN}^{+} \mathrm{Cl}^{-} / \mathrm{SBA}-15$ on one side and $\mathrm{HGIIN}^{+} \mathrm{Cl}^{-} / \mathrm{MCM}-22$ and $\mathrm{HGIIN}^{+} \mathrm{Cl}^{-} / \mathrm{MCM}-56$ on the other side strongly increased (Supporting Information File 1, Figure S4). With $\mathrm{HGIIN}^{+} \mathrm{Cl}^{-}$as a homogeneous catalyst no induction period was discernable at $60{ }^{\circ} \mathrm{C}$ (see [21]), however, the conversion curve at $30{ }^{\circ} \mathrm{C}$ (Supporting Information File 1, Figure S4) suggests a short induction period similar to the reaction with $\mathrm{HGIIN}^{+} \mathrm{Cl}^{-}$/ SBA-15. In all cases, octadecene and dimethyl octadecendioate were the only reaction products.

In order to elucidate the origin of the above mentioned difference in activity of $\mathrm{HGIIN}^{+} \mathrm{Cl}^{-} / \mathrm{SBA}-15$ and $\mathrm{HGIIN}^{+} \mathrm{Cl}^{-} /$

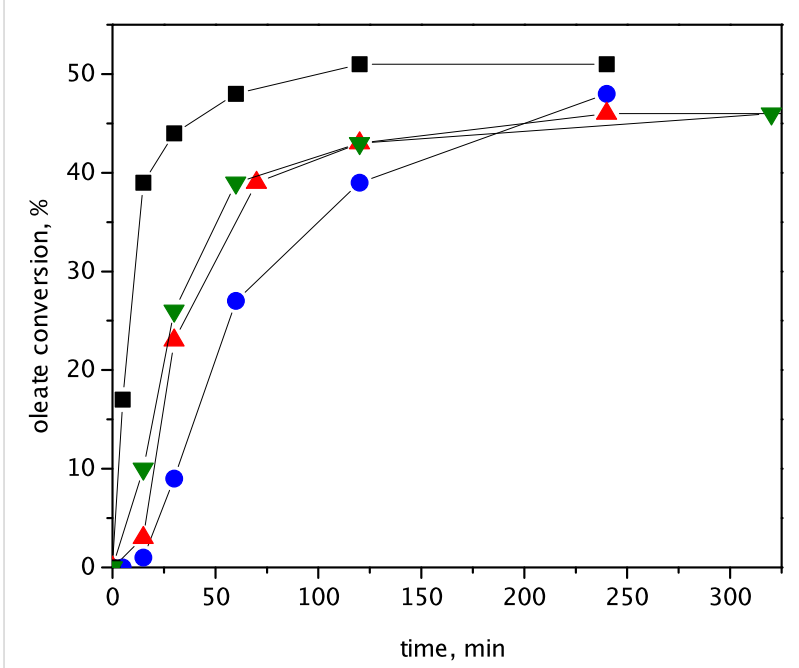

Figure 5: Self-metathesis of methyl oleate over $\mathrm{HGIIN}^{+} \mathrm{Cl}^{-} / \mathrm{SBA}-15$ (घ), $\mathrm{HGIIN}^{+} \mathrm{Cl}^{-} / \mathrm{MCM}-22(\boldsymbol{\Delta}), \mathrm{HGIN}^{+} \mathrm{Cl}^{-} / \mathrm{MCM}^{-56}(\boldsymbol{\nabla})$, and $\mathrm{HGIN}^{+} \mathrm{Cl}^{-} /$ MCM-36 $(\bullet)$. Toluene, $60^{\circ} \mathrm{C}$, molar ratio oleate $/ \mathrm{Ru}=250, \mathrm{col}_{\mathrm{ol}}=$ $0.15 \mathrm{~mol} / \mathrm{L}$.

MCM-22, we performed a study of cross-metathesis (CM) of methyl oleate and cis-3-hexenyl acetate (Scheme 2) over these two catalysts. cis-3-Hexenyl acetate can be considered as a short-chain analogue of methyl oleate. Over both $\mathrm{HGIIN}^{+} \mathrm{Cl}^{-}$/ SBA-15 and $\mathrm{HGIIN}^{+} \mathrm{Cl}^{-} / \mathrm{MCM}-22$ in toluene at $30{ }^{\circ} \mathrm{C}$, cis-3hexenyl acetate reacted quickly, without any induction period, and with $100 \%$ selectivity to 3 -hexene and 1,6-diacetoxy-3hexene. The differences in the reaction rates for both catalysts were marginal (Figure S5, Supporting Information File 1). Splitting test for self-metathesis of cis-3-hexenyl acetate over $\mathrm{HGIIN}^{+} \mathrm{Cl}^{-} / \mathrm{MCM}-22$ (Figure S6, Supporting Information File 1) evidenced no leaching of catalytically active species into the liquid phase, similarly to RCM of (-)- $\beta$-citronellene over $\mathrm{HGIIN}^{+} \mathrm{Cl}^{-} / \mathrm{MCM}-56$. Figure 6 shows conversion curves for $\mathrm{CM}$ of methyl oleate with cis-3-hexenyl acetate (molar ratio 1:1) over both $\mathrm{HGIIN}^{+} \mathrm{Cl}^{-} / \mathrm{MCM}-22$ and $\mathrm{HGIIN}^{+} \mathrm{Cl}^{-} / \mathrm{SBA}-15$ together with conversion curves for self-metatheses of methyl oleate and cis-3-hexenyl acetate over $\mathrm{HGIIN}^{+} \mathrm{Cl}^{-} / \mathrm{MCM}-22$. The induction period characteristic for self-metathesis of methyl oleate over $\mathrm{HGIIN}^{+} \mathrm{Cl}^{-} / \mathrm{MCM}-22$ was minimized in $\mathrm{CM}$ to about $5 \mathrm{~min}$ for both catalysts. The reaction proceeded more quickly over $\mathrm{HGIIN}^{+} \mathrm{Cl}^{-} / \mathrm{MCM}-22$ than over $\mathrm{HGIIN}^{+} \mathrm{Cl}^{-}$/ 


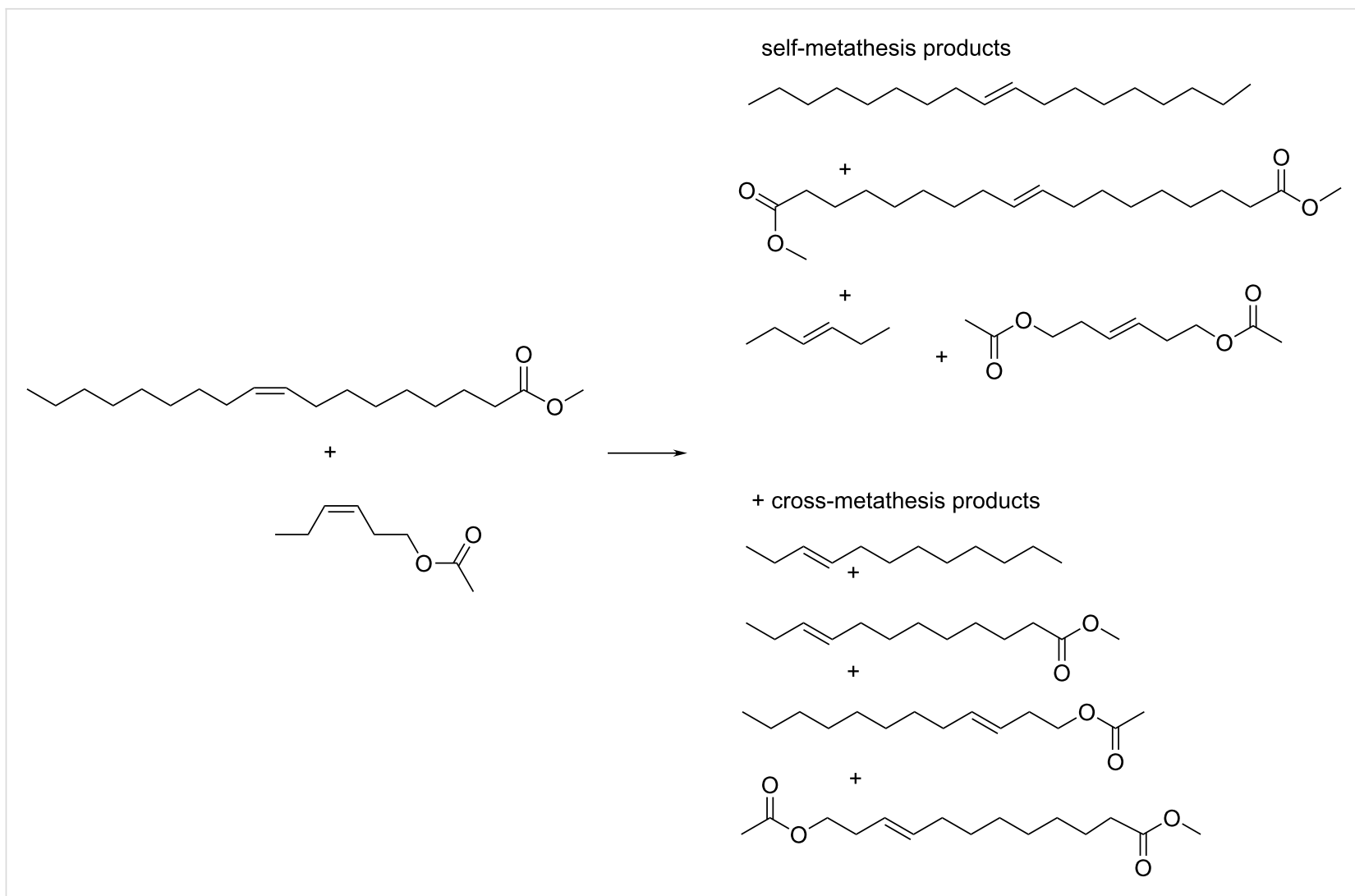

Scheme 2: Cross-metathesis of methyl oleate with cis-3-hexenyl acetate.

SBA-15 (cf. 31\% conversion of methyl oleate at 25 min over $\mathrm{HGIIN}^{+} \mathrm{Cl}^{-} / \mathrm{MCM}-22$ vs $25 \%$ methyl oleate conversion at 30 min over $\mathrm{HGIIN}^{+} \mathrm{Cl}^{-} / \mathrm{SBA}-15$ ). At the beginning of the reaction, the consumption of cis-3-hexenyl acetate prevailed over that of methyl oleate, however, approaching the equilibrium, the consumptions of both reactants were practically the same. In equilibrium, about $75 \%$ of both reactants were consumed. About $23 \%$ of both methyl oleate and cis-3-hexenyl acetate were converted to the self-metathesis products (9-octadecene and 3-hexene were used for GC determination, data not given in Figure 6). The rest (52\%) was converted to the cross-metathesis products according to Scheme 2. It indicates the system approached statistical cross-metathesis, in accord with the characters of both reactants (classes of reactants in $\mathrm{CM}$ according to Grubbs [35]).

The data presented indicated that the depressed activity of $\mathrm{HGIIN}^{+} \mathrm{Cl}^{-} / \mathrm{MCM}-22$ in the self-metathesis of methyl oleate was not connected with a slow diffusion of the reactant to the active centers, but most probably with the slow initiation rate. If initiation starts by coordination of the substrate molecule to the $\mathrm{Ru}$ atom (association and interchange mechanism [36]), the steric conditions around the Ru atom may be important. The very low initiation rate with methyl oleate may implicate some restrictions in coordination of bulky molecules; we can speculate about some confinement in the coordination sphere of $\mathrm{Ru}$ in $\mathrm{HGIIN}^{+} \mathrm{Cl}^{-} / \mathrm{MCM}-22$ (partial immersion of $\mathrm{HGIIN}^{+} \mathrm{Cl}^{-}$into

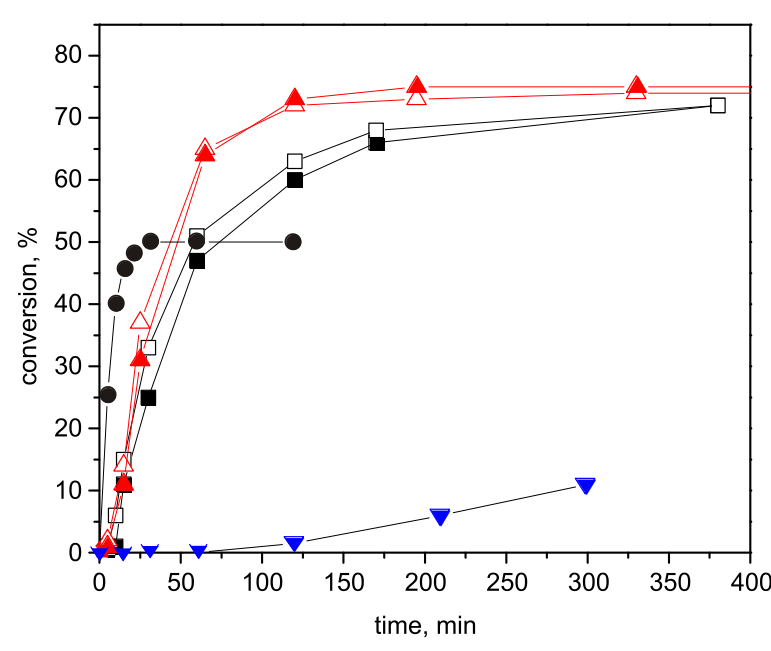

Figure 6: Conversion curves for $\mathrm{CM}$ of methyl oleate (full symbols) with cis-3-hexenyl acetate (open symbols) over $\mathrm{HGINN}^{+} \mathrm{Cl}^{-} / \mathrm{MCM}-22$ $(\boldsymbol{\Delta}, \Delta)$, and $\mathrm{HGINN}^{+} \mathrm{Cl}^{-} / \mathrm{SBA}-15(\mathbf{m}, \square)$ and for self-metathesis of oleate $(\boldsymbol{\nabla})$ and self-metathesis of cis-3-hexenyl acetate $(\bullet)$ both with $\mathrm{HGIIN}^{+} \mathrm{Cl}^{-} / \mathrm{MCM}-22$. Toluene, $30^{\circ} \mathrm{C}$, molar ratio methyl oleate/cis-3hexenyl acetate $/ \mathrm{Ru}=250 / 250 / 1, c_{\mathrm{ol}}=c_{\mathrm{ac}}=0.15 \mathrm{~mol} / \mathrm{L}$. 
support cavities and/or other deformation of the coordination sphere as a result of immobilization). When the initiation passed with cis-3-hexenyl acetate, the created catalytically active centers were able to ensure rapid propagation regardless the kind of substrate molecules.

\section{Conclusion}

Hoveyda-Grubbs type metathesis catalysts with quaternary ammonium tags on NHC ligands $\mathrm{HGIIN}^{+} \mathrm{Cl}^{-}$and $\mathrm{HGIIN}^{+} \mathrm{PF}_{6}{ }^{-}$ were immobilized on lamellar zeolites MCM-22, MCM-56, and MCM-36. Linker-free immobilizations, consisting in mixing zeolite supports with catalyst solutions and stirring the corresponding suspensions at room temperature, were successfully used. Hybrid catalysts formed ( $\mathrm{Ru}$ content from 0.7 to $1.1 \mathrm{wt} \%$ ) exhibited a firm attachment of $\mathrm{Ru}$ species to the support and high stability, which was manifested by a very low $\mathrm{Ru}$ leaching (from 0.1 to $0.6 \%$ of original $\mathrm{Ru}$ content) and possibility of catalyst reusing (five times with $99.5 \%$ conversion).

The surface stoichiometry determined from XPS indicated an ion exchange between zeolite supports ( $\mathrm{Na}$ forms) and the Hoveyda-Grubbs type catalysts. In the case of $\mathrm{HGIIN}^{+} \mathrm{Cl}^{-}$, the unchanged cationic part of the Ru complex was suggested to be present in the hybrid catalyst and the counter anion, $\mathrm{Cl}^{-}$, was suggested to remain in the liquid phase as $\mathrm{NaCl}$; however, in the case of $\mathrm{HGIIN}^{+} \mathrm{PF}_{6}{ }^{-}$, partial decomposition of the $\mathrm{PF}_{6}{ }^{-}$anion and ligand exchange at the Ru atom most likely accompanied the immobilization. The XRD and nitrogen adsorption measurements confirmed that the layered structure of the supports was preserved in the prepared hybrid catalysts.

The activity of hybrid catalysts was studied (i) in RCM of (-)- $\beta$-citronellene and $N, N$-diallyl-2,2,2-trifluoroacetamide, and (ii) in self-metathesis and cross-metathesis of methyl oleate. The activity was compared with that of $\mathrm{HGIIN}^{+} \mathrm{Cl}^{-}$linker-free immobilized on mesoporous molecular sieves SBA-15 $\left(\mathrm{HGIIN}^{+} \mathrm{Cl}^{-} / \mathrm{SBA}-15\right.$, pore diameter $\left.6.6 \mathrm{~nm}\right)$. In $\mathrm{RCM}$ reactions, the activity decreased in the following order of support MCM-22 $\approx$ MCM-56 > SBA-15 > MCM-36. The layered structure of MCM-22 and MCM-56 most likely ensured better access of the reactants to the catalytically active centers as compared to the case of the SBA-15 based hybrid catalyst. In self-metathesis of methyl oleate, $\mathrm{HGIIN}^{+} \mathrm{Cl}^{-} / \mathrm{SBA}-15$ was found to be the most active; the reaction over $\mathrm{HGIIN}^{+} \mathrm{Cl}^{-}$on zeolite supports proceeded slowly and with a large induction period. In contrast to that, in the cross-metathesis of methyl oleate with cis-3-hexenyl acetate over $\mathrm{HGIIN}^{+} \mathrm{Cl}^{-} / \mathrm{MCM}-22$, the induction period was negligible and the reaction rate slightly exceeded that over $\mathrm{HGIIN}^{+} \mathrm{Cl}^{-} / \mathrm{SBA}-15$. This behavior may indicate a slow initiation by methyl oleate due to its slow coor- dination to the Hoveyda-Grubbs type catalysts immobilized on the zeolite supports studied.

\section{Experimental Materials and techniques}

$\mathrm{Ru}$ alkylidene complexes $\mathrm{HGIIN}^{+} \mathrm{Cl}^{-}$and $\mathrm{HGIIN}^{+} \mathrm{PF}_{6}{ }^{-}$were kindly provided by Krzysztof Skowerski (Apeiron Synthesis, Wroclaw, Poland). Zeolites MCM-22, MCM-56 and MCM-36 (Na forms) were prepared according to literature [37-39] as well as mesoporous molecular sieves SBA-15 [40]. Individual supports were calcined under following conditions: MCM-22, MCM-56 in a stream of nitrogen at $482{ }^{\circ} \mathrm{C}$ for $3 \mathrm{~h}$ (heating rate $1{ }^{\circ} \mathrm{C} / \mathrm{min}$ ) and further after cooling down to $100{ }^{\circ} \mathrm{C}$ under air at $540{ }^{\circ} \mathrm{C}$ for $8 \mathrm{~h}$ with a heating rate $1^{\circ} \mathrm{C} / \mathrm{min}$; MCM-36 under air at $540{ }^{\circ} \mathrm{C}$ for $6 \mathrm{~h}$ with a heating rate $2{ }^{\circ} \mathrm{C} / \mathrm{min}$; SBA- 15 in air at $550{ }^{\circ} \mathrm{C}$ for $6 \mathrm{~h}$ (heating rate $1{ }^{\circ} \mathrm{C} / \mathrm{min}$ ).

Toluene (Lach-Ner) was dried for $12 \mathrm{~h}$ over anhydrous $\mathrm{Na}_{2} \mathrm{SO}_{4}$, then distilled with $\mathrm{Na}$, and stored over molecular sieves type $4 \AA$. Dichloromethane (Lach-Ner) was dried overnight over anhydrous $\mathrm{CaCl}_{2}$ then distilled with $\mathrm{CaH}_{2}$. (-)- $\beta$-citronellene (Aldrich, purity of $\geq 90 \%$ ), $N, N$-diallyl-2,2,2-trifluoroacetamide (Aldrich, 98\%), cis-3-hexenyl acetate (Aldrich, purity $\geq 98 \%$ ), and methyl oleate (Research Institute of Inorganic Chemistry, a.s., Czech Rep., purity of $94 \%$, with methyl palmitate, methyl stearate, and methyl linolate being the main impurities) were used after being passed through a column filled with activated alumina.

Nitrogen adsorption/desorption isotherms were measured on a Micromeritics GEMINI II 2370 volumetric Surface Area Analyzer at liquid nitrogen temperature $\left(-196^{\circ} \mathrm{C}\right)$ to determine the surface area and pore volume. Prior to the sorption measurements, all samples were degassed on a Micromeritics FlowPrep060 instrument under helium at $110^{\circ} \mathrm{C}$ for $6 \mathrm{~h}$. X-ray powder diffraction (XRD) data were obtained on a Bruker AXS D8 Advance diffractometer with a graphite monochromator and a Vantec-1 position sensitive detector using $\mathrm{Cu} \mathrm{K} \alpha$ radiation (at $40 \mathrm{kV}$ and $30 \mathrm{~mA}$ ) in Bragg-Brentano geometry.

The X-ray photoelectron spectra (XPS) of the samples were measured using a modified ESCA 3 MkII multitechnique spectrometer equipped with a hemispherical electron analyzer operated in a fixed transmission mode. Al $\mathrm{K} \alpha$ radiation $(1486.6 \mathrm{eV})$ was used for electron excitation. The binding energy scale of the spectrometers was calibrated using the $\mathrm{Au} 4 \mathrm{f}_{7 / 2}(84.0 \mathrm{eV})$ and $\mathrm{Cu} 2 \mathrm{p}_{3 / 2}(932.6 \mathrm{eV})$ photoemission lines. The pressure of residual gases in the analysis chamber during spectra acquisition was $6 \times 10^{-9}$ mbar. The powder samples were spread on an aluminum surface. The spectra were measured at room temperature and collected at a detection angle of $45^{\circ}$ with respect to the 
macroscopic sample surface plane. Survey scan spectra and high-resolution spectra of overlapping Ru $3 \mathrm{~d}+\mathrm{C} 1 \mathrm{~s}$ photoelectrons, and $\mathrm{N} \mathrm{1s}, \mathrm{Cl} 2 \mathrm{p}, \mathrm{P} 2 \mathrm{~s}$, and $\mathrm{F} 1 \mathrm{~s}$ photoelectrons were measured. The spectra were curve-fitted after subtraction of the Shirley background [41] using the Gaussian-Lorentzian line shape and the damped nonlinear least-squares algorithms (software XPSPEAK 4.1) [42]. The quantification of elemental concentrations was accomplished by correcting integrated intensities of photoelectron peaks for the transmission function of the electron analyzer and the pertinent photoionization cross sections [43]. In the calculations, a homogeneous composition of the analyzed layer of the measured samples was assumed. The typical error for the quantitative analysis by XPS was approximately $10 \%$ [44].

The determination of the ruthenium content was performed by inductively coupled plasma mass spectrometry (ICP-MS) by the Institute of Analytical Chemistry (ICT, Prague, Czech Republic).

\section{Catalyst preparation}

Immobilization of $\mathrm{HGIIN}^{+} \mathrm{X}^{-}$complexes was performed by stirring a mixture of complex and support in $\mathrm{CH}_{2} \mathrm{Cl}_{2}$ at room temperature $(3 \mathrm{~h})$ under argon atmosphere. Details are given elsewhere [21]. For immobilization, calcined (dehydrated) supports $\left(300^{\circ} \mathrm{C}, 3 \mathrm{~h}\right)$ were used. The amount of support, $\mathrm{Ru}$ complex submitted and $\mathrm{Ru}$ content in hybrid catalyst are given in Table 4. Catalyst prepared by immobilization of $\mathrm{HGIIN}^{+} \mathrm{Cl}^{-}$ on MCM-22 was labelled as $\mathrm{HGIIN}^{+} \mathrm{Cl}^{-} / \mathrm{MCM}-22$; other catalysts were labelled in a similar way.

\section{Testing of catalyst activity}

Metathesis reactions were performed under Ar atmosphere in Schlenk tubes equipped with magnetic stirring bars. In a typical RCM experiment the amount of catalyst corresponding to $1 \mu \mathrm{mol}$ of $\mathrm{Ru}$ was put into the reactor, then toluene $(13 \mathrm{~mL})$ was added and the suspension was heated to $60^{\circ} \mathrm{C}$. The reaction was started by addition of $(-)$ - $\beta$-citronellene $(2 \mathrm{mmol})$ under stirring $(900 \mathrm{rpm})$. At given time intervals, samples $(0.1 \mathrm{~mL})$ were taken and quenched with ethyl vinyl ether, and after centrifugation, the supernatants were analyzed by gas chromatography (GC). In the cross-metathesis experiment, a mixture of methyl oleate $(0.25 \mathrm{mmol})$ and cis-3-hexenyl acetate $(0.25 \mathrm{mmol})$ was added to the suspension of catalyst ( $1 \mu \mathrm{mol}$ of $\mathrm{Ru})$ in toluene $(1.7 \mathrm{~mL})$ at $30^{\circ} \mathrm{C}$ under stirring. The sampling, quenching and analysis steps were performed similarly as for RCM of $(-)$ - $\beta$-citronellene.

A high-resolution gas chromatograph (Agilent model 6890) with a DB-5 column (length of $50 \mathrm{~m}$, inner diameter of $320 \mu \mathrm{m}$, stationary phase thickness of $1 \mu \mathrm{m}$ ) equipped with FID detector was used for reaction product analysis. Temperature programs were: (i) from $80{ }^{\circ} \mathrm{C}$ to $260{ }^{\circ} \mathrm{C}$ with ramp $20{ }^{\circ} \mathrm{C} / \mathrm{min}$ for $(-)-\beta$-citronellene products, and (ii) from $80{ }^{\circ} \mathrm{C}$ to $325{ }^{\circ} \mathrm{C}$ with ramps $5{ }^{\circ} \mathrm{C}$ and $20^{\circ} \mathrm{C}$ for methyl oleate and DAF products. Retention times (in min) were 8.63 (citronellene), 4.88 (methylcyclopentene), 19.3 (DAF), 19.7 ( $N$-(2-trifluoroacetyl)-2,5dihydropyrrole), 41.3 (methyl oleate), 33.9 (octadecene), and 57.5 (diester). $n$-Nonane was used as an internal standard, whenever required. Individual products (all are known compounds) were identified by gas chromatography and mass spectrometry (GC-MS) (ThermoFinnigan, FOCUS DSQ II Single Quadrupole). The absolute error in the determination of conversion was $\pm 2 \%$.

\section{Supporting Information}

\section{Supporting Information File 1}

XRD patterns of catalysts and supports, conversion curves for self-metatheses of methyl oleate and cis-3-hexenyl acetate, splitting experiment.

[http://www.beilstein-journals.org/bjoc/content/ supplementary/1860-5397-11-225-S1.pdf]

Table 4: Amounts of support and $\mathrm{HGIIN}^{+} X$ used for preparation of hybrid catalysts.

\begin{tabular}{|c|c|c|c|c|}
\hline Catalyst & $\begin{array}{l}\text { Weight of } \\
\text { support } \\
\text { (mg) }\end{array}$ & $\begin{array}{l}\text { Weight of } \\
\text { HGIIN }^{+} X^{-} \\
(\mathrm{mg})\end{array}$ & $\begin{array}{l}\text { Ru content } \\
\text { in catalyst } \\
\text { (wt \%) }\end{array}$ & $f^{a}$ \\
\hline $\mathrm{HGIN}^{+} \mathrm{Cl}^{-} / \mathrm{MCM}-22$ & 250 & 23.9 & 1.1 & 0.97 \\
\hline $\mathrm{HGIN}^{+} \mathrm{PF}_{6}{ }^{-} / \mathrm{MCM}-22$ & 140 & 17.8 & 0.9 & 0.66 \\
\hline $\mathrm{HGIN}^{+} \mathrm{Cl}^{-} / \mathrm{MCM}-56$ & 305 & 30.2 & 1.1 & 0.99 \\
\hline $\mathrm{HGIN}^{+} \mathrm{Cl}^{-} / \mathrm{MCM}-36$ & 835 & 87.0 & 0.7 & 0.54 \\
\hline $\mathrm{HGIN}^{+} \mathrm{Cl}^{-} / \mathrm{SBA}-15$ & 339 & 36.5 & 1.2 & 0.99 \\
\hline
\end{tabular}

$a_{f}=$ fraction of $R u$ attached to the support. 


\section{Acknowledgements}

The authors thank K. Skowerski (Apeiron Synthesis, Wroclaw, Poland) for the samples of Ru catalysts and M. Horáček (J. Heyrovský Institute, Prague) for GC-MS analysis. Financial support from Grant Agency of the Czech Republic (P106/12/ 0189) is gratefully acknowledged.

\section{References}

1. Buchmeiser, M. R. Chem. Rev. 2009, 109, 303-321. doi:10.1021/cr800207n

2. Copéret, C.; Basset, J.-M. Adv. Synth. Catal. 2007, 349, 78-92. doi:10.1002/adsc.200600443

3. Balcar, H.; Roth, W. J. Hybrid Catalysts for Olefin Metathesis and Related Polymerizations. In New and Future Developments in Catalysis. Hybrid Materials, Composites, and Organocatalysts; Suib, S. L., Ed.; Elsevier: Amsterdam, The Netherlands, 2013; pp 1-26. doi:10.1016/B978-0-444-53876-5.00001-5

4. Buchmeiser, M. R. Immobilization of Olefin Metathesis Catalysts. In Olefin Metathesis, Theory and Practice; Grela, K., Ed.; John Wiley \& Sons, Inc.: Hoboken, NJ, USA, 2014. doi:10.1002/9781118711613.ch20

5. Balcar, H.; Čejka, J. Coord. Chem. Rev. 2013, 257, 3107-3124. doi:10.1016/j.ccr.2013.07.026

6. Bek, D.; Balcar, H.; Žilková, N.; Zukal, A.; Horáček, M.; Čejka, J. ACS Catal. 2011, 1, 709-718. doi:10.1021/cs200090e

7. Pastva, J.; Čejka, J.; Žilková, N.; Mestek, O.; Rangus, M.; Balcar, H. J. Mol. Catal. A: Chem. 2013, 378, 184-192. doi:10.1016/j.molcata.2013.06.006

8. Shinde, T.; Varga, V.; Polášek, M.; Horáček, M.; Žilková, N.; Balcar, H. Appl. Catal., A 2014, 478, 138-145. doi:10.1016/j.apcata.2014.03.036

9. Drozdzak, R.; Allaert, B.; Ledoux, N.; Dragutan, I.; Dragutan, V.; Verpoort, F. Coord. Chem. Rev. 2005, 249, 3055-3074. doi:10.1016/j.ccr.2005.05.003

10. Zhang, H.; Li, Y.; Shao, S.; Wu, H.; Wu, P. J. Mol. Catal. A: Chem. 2013, 372, 35-43. doi:10.1016/j.molcata.2013.01.034

11. Li, L.; Shi, J.-I. Adv. Synth. Catal. 2005, 347, 1745-1749. doi:10.1002/adsc.200505066

12. Elias, X.; Pleixats, R.; Man, M. W. C. Tetrahedron 2008, 64, 6770-6781. doi:10.1016/j.tet.2008.04.113

13. Dragutan, I.; Dragutan, V. Platinum Met. Rev. 2008, 52, 71-82. doi:10.1595/147106708X297477

14. Van Berlo, B.; Houthoofd, K.; Sels, B. F.; Jacobs, P. A. Adv. Synth. Catal. 2008, 350, 1949-1953. doi:10.1002/adsc.200800211

15. Yang, H.; Ma, Z.; Wang, Y.; Wang, Y.; Fang, L. Chem. Commun. 2010, 46, 8659-8661. doi:10.1039/c0cc03227a

16. Balcar, H.; Shinde, T.; Žilková, N.; Bastl, Z. Beilstein J. Org. Chem. 2011, 7, 22-28. doi:10.3762/bjoc.7.4

17. Schachner, J. A.; Cabrera, J.; Padilla, R.; Fischer, C.; van der Schaaf, P. A.; Pretot, R.; Rominger, F.; Limbach, M. ACS Catal. 2011, 1, 872-876. doi:10.1021/cs2002109

18. Cabrera, J.; Padilla, R.; Bru, M.; Lindner, R.; Kageyama, T.; Wilckens, K.; Balof, S. L.; Schanz, H.-J.; Dehn, R.; Teles, J. H.; Deuerlein, S.; Müller, K.; Rominger, F.; Limbach, M. Chem. - Eur. J. 2012, 18, 14717-14724. doi:10.1002/chem.201202248
19. Cabrera, J.; Padilla, R.; Dehn, R.; Deuerlein, S.; Gułajski, Ł.; Chomiszczak, E.; Teles, J. H.; Limbach, M.; Grela, K. Adv. Synth. Catal. 2012, 354, 1043-1051. doi:10.1002/adsc.201100863

20. Bru, M.; Dehn, R.; Teles, J. H.; Deuerlein, S.; Danz, M.; Müller, I. B.; Limbach, M. Chem. - Eur. J. 2013, 19, 11661-11671. doi:10.1002/chem.201203893

21. Pastva, J.; Skowerski, K.; Czarnocki, S. J.; Žilková, N.; Čejka, J.; Bastl, Z.; Balcar, H. ACS Catal. 2014, 4, 3227-3236. doi:10.1021/cs500796u

22. Skowerski, K.; Pastva, J.; Czarnocki, S. J.; Janoscova, J. Org. Process Res. Dev. 2015, 19, 872-877. doi:10.1021/acs.oprd.5b00132

23. Roth, W. J.; Nachtigall, P.; Morris, R. E.; Čejka, J. Chem. Rev. 2014, 114, 4807-4837. doi:10.1021/cr400600f

24. Choi, M.; Na, K.; Kim, J.; Sakamoto, Y.; Terasaki, O.; Ryoo, R. Nature 2009, 461, 246-249. doi:10.1038/nature08288

25. Eliášová, P.; Opanasenko, M.; Wheatley, P. S.; Shamzhy, M.; Mazur, M.; Nachtigall, P.; Roth, W. J.; Morris, R. E.; Čejka, J. Chem. Soc. Rev. 2015, 44, 7177-7206. doi:10.1039/c5cs00045a

26. Roth, W. J.; Čejka, J. Catal. Sci. Technol. 2011, 1, 43-53. doi:10.1039/c0cy00027b

27. Roth, W. J.; Nachtigall, P.; Morris, R. E.; Wheatley, P. S.; Seymour, V. R.; Ashbrook, S. E.; Chlubná, P.; Grajciar, L.; Položij, M.; Zukal, A.; Shvets, O.; Čejka, J. Nat. Chem. 2013, 5, 628-633. doi:10.1038/nchem.1662

28. Morris, R. E.; Čejka, J. Nat. Chem. 2015, 7, 381-388. doi:10.1038/nchem.2222

29. Zukal, A.; Dominguez, I.; Mayerová, J.; Čejka, J. Langmuir 2009, 25, 10314-10321. doi:10.1021/la901156z

30. Opanasenko, M.; Štěpnička, P.; Čejka, J. RSC Adv. 2014, 4, 65137-65162. doi:10.1039/C4RA11963K

31. Juttu, G. G.; Lobo, R. F. Microporous Mesoporous Mater. 2000, 40, 9-23. doi:10.1016/S1387-1811(00)00233-X

32. Díaz, U.; Corma, A. Dalton Trans. 2014, 43, 10292-10316. doi:10.1039/c3dt53181c

33. Phan, N. T. S.; Van Der Sluys, M.; Jones, C. W. Adv. Synth. Catal. 2006, 348, 609-679. doi:10.1002/adsc.200505473

34. European Medicines Agency, Pre-authorisation Evaluation of Medicines for Human Use, Guideline on the specification limits for residues on metal catalyst. London, January 2007.

35. Chatterjee, A. K.; Choi, T.-L.; Sanders, D. P.; Grubbs, R. H. J. Am. Chem. Soc. 2003, 125, 11360-11370. doi:10.1021/ja0214882

36. Nelson, D. J.; Manzini, S.; Urbina-Blanco, C. A.; Nolan, S. P. Chem. Commun. 2014, 50, 10355-10375. doi:10.1039/C4CC02515F

37. Kresge, C. T.; Roth, W. J.; Simmons, K. G.; Vartuli, J. C. Crystalline Oxide Material. U.S. Patent 5,229,341, June 20, 1993.

38. Fung, A. S.; Lawton, S. L.; Roth, W. J. Synthetic Layered MCM-56, Its Synthesis And Use. U.S. Patent 5,362,697, Nov 8, 1994.

39. Roth, W. J.; Kresge, C. T.; Vartuli, J. C.; Leonowicz, M. E.; Fung, A. S.; McCullen, S. B. Stud. Surf. Sci. Catal. 1995, 94, 301-308. doi:10.1016/S0167-2991(06)81236-X

40. Topka, P.; Balcar, H.; Rathouský, J.; Žilková, N.; Verpoort, F.; Čejka, J. Microporous Mesoporous Mater. 2006, 96, 44-54. doi:10.1016/j.micromeso.2006.06.016

41. Shirley, D. A. Phys. Rev. B 1972, 5, 4709-4714. doi:10.1103/PhysRevB.5.4709

42. Kwok, R. W. M.: Dept. of Chemistry, Chinese University of Hong Kong, Shatin, Hong Kong, http://www.uksaf.org/xpspeak41.zip. A freeware program. 
43. Scofield, J. H. J. Electron Spectrosc. Relat. Phenom. 1976, 8 , 129-137. doi:10.1016/0368-2048(76)80015-1

44. Briggs, D. J.; Grant, T., Eds. Surface Analysis by Auger and X-Ray Photoelectron Spectroscopy; Cromwell Press: Trowbridge, 2003.

\section{License and Terms}

This is an Open Access article under the terms of the Creative Commons Attribution License

(http://creativecommons.org/licenses/by/2.0), which permits unrestricted use, distribution, and reproduction in any medium, provided the original work is properly cited.

The license is subject to the Beilstein Journal of Organic Chemistry terms and conditions:

(http://www.beilstein-journals.org/bjoc)

The definitive version of this article is the electronic one which can be found at:

doi:10.3762/bjoc. 11.225 